\title{
Swedish Relative Clauses as Weak Islands
}

\author{
Filippa Lindahl* \\ LSA Annual Meeting, Portland, January 8-11, 2015
}

1. Introduction and background. Swedish exhibits long-distance dependencies in which an antecedent outside of a relative clause (RC) is associated with an RC-internal gap. The phenomenon, also familiar from Danish and Norwegian, is called relative clause extraction (RCE), and is of interest from a theoretical perspective since it seems to violate purportedly universal locality conditions (i.e. the Complex NP Constraint (Ross 1967), Subjacency (Chomsky 1973) and the Phase Impenetrability Condition (Chomsky 2001)).

Some recent analyses of Scandinavian RCE rely on the assumption that extraction is possible only from subject RCs (Kush, Omaki \& Hornstein 2013), or that extraction from subject RCs should be analyzed differently than extraction from non-subject RCs (Platzack 2014). Common to these two accounts is that they argue that the relation between the (apparent) RC head and RC complementizer in subject RCs is not mediated by an $\overline{\mathrm{A}}$-dependency.

In this paper, I show that extraction is possible from non-subject RCs as well, and argue that examples like (1) involve two $\bar{A}$-dependencies.

(1) [Den där halloweenmasken $]_{i}$ vill Edith hitta någon ${ }_{k} \quad$ som hon kan skrämma $\_k_{k}$ med $\_i$ the there Halloween mask-DEF want Edith find someone REL she can scare with

'Edith wants to find someone that she can scare with that Halloween mask.'

Some similar examples have been noted by Engdahl (1997), Koch Christensen (1982), and others, but here I present new evidence from crossover, connectivity effects, and parasitic gap licensing, showing that both of the dependencies pattern with $\bar{A}$-movement with respect to these properties.

A common distinction in previous research on syntactic locality is that between strong and weak islands. Strong islands are structures out of which no extraction is possible, whereas weak islands are structures out of which some, but not all, phrases can be extracted (Szabolcsi 2006, p. 480). One proposal for the analysis of weak islands is the algebraic approach. Here, weak islands are taken to be a semantic phenomenon: Phrases that can be extracted denote individuals, which can be collected into sets that form Boolean algebras. Extraction of phrases that denote non-individuals, which cannot be collected into such sets, yields weak island violations (Szabolcsi 2006). RCs are commonly taken to be the prototypical example of strong islands, making Scandinavian RCE unexpected.

Against this background we may ask two questions: 1. How are examples like (1), with extraction from non-subject RCs, derived? 2. Which kinds of phrases can be extracted from non-subject RCs?

2. Two Ā-movement dependencies. $\bar{A}$-movement is commonly associated with a number of characteristics: it creates a gap, it is apparently unbounded, it licenses parasitic gaps, it induces crossover effects and connectivity effects, and it is sensitive to islands. Examples (2)-(5) demonstrate that both the dependency between the RC-external antecedent and the RC-internal gap, and

${ }^{*}$ Thanks are due to Maia Andréasson, Sandy Chung, Amy Rose Deal, Elisabet Engdahl, Jens Larsson, Jim McCloskey, Nick Kalivoda, Erik Zyman, and participants at S-Circle at UC Santa Cruz and the Grammar seminar at Lund University where I have presented earlier versions of this work, for greatly contributing to my thinking on the topic. Author: Filippa Lindahl, University of Gothenburg (filippa.lindahl@ svenska.gu.se). 
the dependency creating the RC, have characteristics of $\overline{\mathrm{A}}$-movement. Table 1 sums up the results of the other diagnostics, which all point towards the same conclusion.

2.1. Ā-Movement out of THE RC. Below we see evidence for $\bar{A}$-movement out of the RC from parasitic gap licensing (2) and case connectivity (3).

(2) Ett av $\operatorname{problemen}_{i} \quad$ kommer jag verkligen inte på något ${ }_{k} \quad$ jag kan göra $\_k$ åt $\_i$ rg [utan att one of problems-DEF come I really not on something I can do for w/o to förvärra $-i \mathrm{pg}]$.

make worse

'One of the problems, I cannot think of anything to do about without making it worse.'

(3) $\operatorname{Dig}_{i} / * \mathrm{Du}_{i} \quad$ vet jag inget $\operatorname{språk}_{k} \quad\left[\right.$ de kan tala $\_k$ med $\left.\_i\right]$. you-ACC/you-NOM know I no language they can speak with

'I know of no language they can speak to you in.'

2.2. $\bar{A}$-MOVEMENT INSIDE THE RC. In (4) we see that relativization licenses parasitic gaps and in (5) that it induces weak crossover effects, indicating that it involves an $\bar{A}$-movement dependency.

(4) [Den där halloweenmasken $]_{i}$ vill jag hitta någon ${ }_{k}$ rg som jag kan skrämma _k med _i utan the there Halloween mask-DEF I want find someone REL I can scare with without att ge $\_k$ pg en alltför stor chock. INF give a too big shock

'I want to find someone who I can scare with that Halloween mask without giving them too big of a shock.'

(5) *[Den där halloweenmasken $]_{i}$ känner jag en tjej som hennes $_{k}$ syster skrämde $\_k$ med $\_i$. the there Halloween mask-DEF know I a girl REL her sister scared with

Note that (4) and (5) show that relativization patterns with $\bar{A}$-movement even when a phrase is extracted from the RC.

2.3. SUMMING UP.

TABLE 1: Diagnostics for $\bar{A}$-movement

\begin{tabular}{lcc} 
Diagnostic & $\begin{array}{c}\text { Extraction } \\
\text { from RC }\end{array}$ & $\begin{array}{c}\text { Movement } \\
\text { inside RC }\end{array}$ \\
\hline Creates a gap & yes & yes \\
Apparent unboundedness & yes & yes \\
Parasitic gap licensing & yes & yes \\
Crossover effects & yes & yes \\
Case connectivity & yes & n.a. \\
Violates CSC and SSC & yes & yes \\
\hline
\end{tabular}

3. Analysis. Given the observations in $§ 2$, I propose that Swedish RCs have multiple CP specifiers, and that movement to the outer specifier is driven by discourse-related features. 
3.1. Multiple CP-SPeCifiers. Chomsky (2001) introduces the Phase Impenetrability Condition (PIC), which is commonly employed to account for locality conditions on movement.

\section{Phase Impenetrability Condition}

The domain of $\mathrm{H}$ is not accessible to operations outside HP; only $\mathrm{H}$ and its edge are accessible to such operations (Chomsky 2001, p. 13).

Assuming that $\mathrm{CP}$ is a phase, we are forced to conclude that relative $\mathrm{C}$ in Swedish must tolerate multiple specifiers. In (6) we see an intermediate step in the derivation of (1). The RC-operator moves to the first Spec-CP, and the extracted phrase to an outer Spec-CP.

(6)

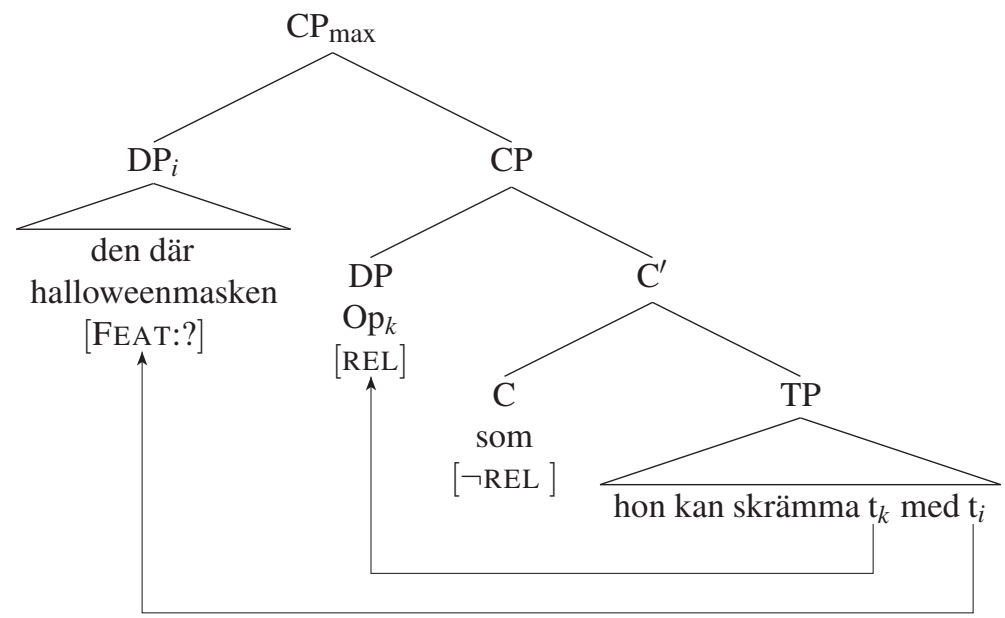

3.2. WHICH PHRASES CAN BE EXTRACTED? Topics of various types can be extracted (cf. Engdahl \& Lindahl 2014), both DP arguments as in (1), PP arguments as in (7), and adjuncts as in (8). But not just any phrase can move out of the RC (9).

(7) $\quad[\text { Till henne }]_{i}$ vet jag ingenting $k_{k}$ jag kan ge $\quad-k \_i$.

to her know I nothing I can give

'I don't know of anything I can give to her.'

(8) $[\text { Så sent }]_{i}$ vet jag ingen ${ }_{k}$ som jag kan ringa till $\_k \_i$. that late know I no one REL I can call to

'I don't know of anyone that I can call that late.'

(9) *Varför ${ }_{i}$ känner du många [som blev sena till festen _ $i$ ] why know you many REL became late to party-DEF

According to Szabolcsi's definition then, Swedish RCs are weak islands. Notably, however, examples like (8) are not expected on Szabolcsi's semantic account. Neither are examples like (10b), which is possible in the relevant context, given in (10a).

a. A: Hur sent kan vi gå och handla?

how late can we go and shop

'How late can we go to the store?' 


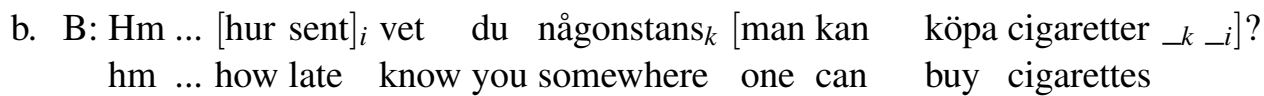
'What is the latest time such that you know of a place
where you could get cigarettes that is open at that time?'

The extracted phrase has to be linked to the discourse. This is also true of individual-level phrases (11) (cf. Pesetsky 1987).

(11) $[\text { Vilken halloweenmask }]_{i} /{ }^{?} \operatorname{Vad}_{i}$ vill Edith hitta någon ${ }_{k} \quad[$ som hon kan skrämma _k med _i $]$ ? which halloween mask/ what wants Edith find someone REL she can scare with

'Which Halloween mask/What does Edith want to find someone that she can scare with?'

This means that it is not straightforward to extend Szabolcsi's semantic account of weak islands to the case of Swedish RCE. Instead I propose that the phrases that can move out of RCs carry one of a natural class of discourse-related features (DR). The C-heads in RCs attract DR-marked phrases, making them available in later stages of the derivation, as illustrated in (12).

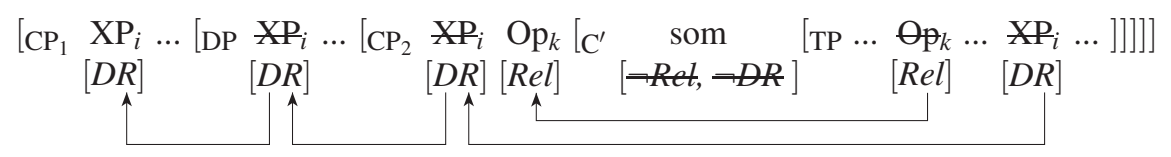

4. Concluding remarks. The paper shows that extraction from non-subject RCs involves two $\overline{\mathrm{A}}$-movement dependencies. Swedish RCs are a species of weak islands, but Szabolcsi's algebraic approach cannot easily be extended to account for them, since the analysis of the Swedish data needs to involve features that relate to the discourse context. An analysis in terms of multiple specifiers of these RCs captures the data, but we no longer have an explanation for the difference between languages like mainland Scandinavian and English. This raises questions for a purely phase-based account of island phenomena.

\section{References}

Chomsky, Noam. 1973. Conditions on transformations. In Stephen R. Anderson \& Paul Kiparsky (eds.), A festschrift for Morris Halle. 232-286. Cambridge, MA: MIT Press.

Chomsky, Noam. 2001. Derivation by phase. In Michael Kenstowicz (ed.), Ken Hale: A life in language. 1-52. Cambridge, MA: MIT Press.

Engdahl, Elisabet. 1997. Relative clause extractions in context. Working Papers in Scandinavian Syntax 60. 51-79.

Engdahl, Elisabet \& Filippa Lindahl. 2014. Preposed object pronouns in mainland Scandinavian. Working Papers in Scandinavian Syntax 92. 1-32. http://projekt.ht.lu.se/uploads/media/WPSS_92.pdf. (18 March, 2015.)

Koch Christensen, Kirsti. 1982. On multiple filler-gap constructions in Norwegian. In Elisabet Engdahl \& Eva Ejerhed (eds.) Readings on unbounded dependencies in the Scandinavian languages. 77-98. Umeå: Univ.

Kush, Dave, Akira Omaki \& Norbert Hornstein. 2013. Microvariation in islands? In Jon Sprouse \& Norbert Hornstein (eds.), Experimental syntax and island effects. 239-265. Cambridge, MA: Cambridge University Press.

Lindahl, Filippa. 2014. Relative clauses are not always strong islands. Working Papers in Scandinavian Syntax 93. 125. http://projekt.ht.lu.se/uploads/media/WPSS_93.pdf. (18 March, 2015.)

Pesetsky, David. 1987. Wh-in-situ: Movement and unselective binding. In Eric J. Reuland \& Alice G. B. ter Meulen (eds.), The Representation of (In)definiteness. Cambridge, MA: MIT Press.

Platzack, Christer. 2014. A feature driven account of mainland Scandinavian extraction from relative clauses. Talk given at Grammatikseminariet in Lund, 3 April 2014.

Ross, John. R. R. 1967. Constraints on variables in syntax. Camebridge, MA: MIT Dissertation.

Szabolcsi, Anna. 2006. Strong vs. weak Islands. In Martin Everaert \& Henk van Riemsdijk (eds), The Blackwell companion to syntax. vol. 4. Malden, MA: Blackwell. 